\title{
EPISTEMOLOGI MANUSIA SEBAGAI KHALIFAH DI ALAM SEMESTA
}

\author{
Salamah Eka Susanti*
}

\begin{abstract}
In much literature that discusses the existence of humans in the universe is always associated with the concept of human caliphate on earth and the concept of worship. The position of humans in the universe that is mandated as Khalifatullah Fi al-Ardh has a moral responsibility in carrying out the function of the caliphate. The relationship between humans and the universe, including human relationships with other bumans, is not a relationship between the ruler and the mastered, but a relationship that has the same goal that is worth worship, namely obedience to God. Because even if humans are able to master, but it is not because of the strength they have, but it is caused by God who subdues it to humans. That is, leadership and human power must still be placed within the framework of human existence that is temporary, so that the tendency of leadership or power can be avoided, which can consequently damage the order of life.
\end{abstract}

Keywords: Epistemology, Man, Caliph, Cosmos.

\section{PENDAHULUAN}

Pemikiran tentang hakikat manusia, dari zaman klasikhingga zaman sekarang tak henti-hentinya di bahas dan di kaji. Pembahasan tentang hakikat manusia inilah yang menyebabkan orang tak henti-hentinya berusaha mencari jawaban tentang pertanyaan filosofis tentang manusia

* Penulis adalah Dosen Tetap Fakultas Tarbiyah Program Studi Pendidikan Agama Islam Institut Ilmu Keislaman Zainul Hasan (INZAH) Kraksaan Probolinggo. 
yaitu apa, dari mana dan ke mana manusia itu. ${ }^{1}$

Teori yang mengkaji tentang hakikat manusiayang sering kita sebut, terutama dalam disiplin keilmuan filsafat terdapat empat aliran; yaitu Pertama, aliran serba zat atau materi; kedua, aliran serba ruh; ketiga, aliran dualismedan keempat, aliran eksistensialisme.

Pembahasan yang pertama kita membahas tentang aliran serba zat atau materi, dimana aliran ini mengatakan bahwa yang benar-benar ada hanyalah zat atau materi saja. Zat atau materi merupakan hakikat dari segala sesuatu. Termasuk alam semesta ini, juga tergolong jenis manusiayang disebut dengan zat atau materi.

Manusia sebagai makhluk materi, maka pertumbuhannya berproses dari materi, yaitu dari sel telur wanitayang bercampur dengan sperma laki-laki, dimana dari percampuran antar sel telur dengan sperma tumbuh menjadi janin yang akhirnya lahir ke dunia sebagai manusia. ${ }^{2}$ Sedangkan yang di sebut dengan ruh atau jiwa itu sendiri adalah pikiran, perasaan (tanggapan, kemauan, kesadaran, ingatan, khayalan, asosiasi, penghayatan dan lain sebagainya). Sedangkan zat atau materi merupakan sel-sel tubuh. ${ }^{3}$ Oleh karena itu, manusia sebagai makhluk materi, maka semua kebutuhanmereka bersifat materi juga, misalnya; ia akan merasa bahagia, dengan adanya materi juga, maka tidaklah mengherankan jika manusia bersifat materialistis. Materi terwujud hanya di dunia, maka pandangan materialistis itu tertuju dengan pandangan hidup yang bersifat duniawi, sedangkan hal-hal yang bersifat ukhrawi dianggap sebagai hal yang tidak nyata.

Sedangkan aliran yang kedua termasuk aliran serba ruh. Aliran ini berpandanganbahwa segala hakikat sesuatu yang wujud di dunia ini ialah "ruh". ${ }^{4}$ Begitu juga dengan hakikat manusia yaitu berupa "ruh". Adapun Jasad atau zat itu adalah manifestasi daripada ruh. Dasar pokokpemikiran aliran serba ruh ini ialah bahwa ruh itu lebih berharga, lebih tinggi nilanya

1 Zuhairini, dkk, Filsafat Pendidikan Islam, (Jakarta: Bumi Aksara, cet. 2, 1995), hal. 71 .

2 Ibid., hal. 72.

3 Ibid., hal.71-72.

4 Ruh ialah sesuatu yang tidak menempati ruang, sehingga tak dapat disentuh dan dilihatoleh panca indera. Hal ini berbeda dengan materi yang menempati ruang sekecil apapun. Istilah lain yang merupakan sinonim dari ruh yang ialah jiwa, sukma, nyawa, semangat dan lain-lain. Materi adalah penjelmaan ruh. Ibid., hal. 72. 
dari pada materi. Hal ini dapat dibuktikan dalam kehidupan sehari-hari. ${ }^{5}$ Adapun Aliran yang terakhir adalah aliran dualism. Aliran ini menggabungkan antara dua aliran yaitu aliran serba zat dengan aliran serba ruh. Aliran ini berpandangan bahwa manusia hakikatnya terdiri dari dua substansi yaitu jasmani dan rohani, badan dan ruh. Dua substansi ini merupakan unsur asal terciptanya manusia yang mana kedua unsur tersebut saling terkait. Badan tidak berasal dari ruh, sebaliknya ruh juga tidak berasal dari badan. Hanya dalam perwujudannya, manusia serba dua, jasad dan ruh. Artinya, antara keduanya saling mempengaruhi. ${ }^{6}$

Pembicaraan tentanghakikat manusia ternyata terus-menerus tak kunjung berakhir. Orang belum merasa puas dengan pandanganpandangan di atas, baik dari aliran serba zat, serba ruh maupun aliran dualisme. Ahli filsafat modern memunculkan teori baru tentang hakikat manusia, yang disebut dengan aliran eksistensialisme. Aliran ini berpandangan bagaimana eksistensi manusia atau wujud manusia itu sesungguhnya. ${ }^{7}$ Aliran eksistensialisme ini pada intinya hakikat manusia yaitu apa yang menguasai manusia secara menyeluruh. Kaum eksistensialis memandang manusia dari segi eksistensi manusia itu sendiri, yaitu cara beradanya manusia itu sendiri di dunia ini.

Dengan beberapa pemaparan yang sudah dijelaskan tentang hakikat manusia diatas, bahwa pemikiran tentang apa, dimana, dan kemana manusia itu akan selalu menjadi kajian, termasuk konsep Islam tentang bagaimana hakikat manusia sebagai Khalifah di alam semesta ini.

\section{PEMBAHASAN}

\section{A. Hakikat Manusia}

What is a man? Pertanyaan ini seringkali diajukan ketika memulai membahas tentang filsafat. ${ }^{8}$ Mengapa demikian? karenapada awalnya, filsafat senantiasa mempersoalkan tentang jati diri manusia. Begitu jugadalam pembahasan tentangpendidikan Islam. Pendidikan Islam tidak akanmempunyai paradigma yang sempurna tanpa menentukan konsep

${ }^{5}$ Ibid.,hal. 73.

${ }^{6}$ Ibid.

7 Ibid., hal. 73.

${ }^{8}$ Jujun S. Suriasumantri, Filsafat Ilmu: Sebuah Pengantar Populer, (Jakarta: Pustaka Sinar Harapan), cet. X, hal. 27. 
filosofis hakikat manusia, sebab pendidikan Islam ditujukan kepada manusia. Dalam konteks ini, manusia memiliki delapan prinsip filosofis, ${ }^{9}$ yaitu sebagai berikut:

1. Manusia adalah makhluk paling mulya di alam ini. Allah telah membekalinya dengan keistimewaan-keistimewaan yang menyebabkan ia behak mengungguli makhluk lain. ${ }^{10}$

2. Kemuliaan manusia atas makhluk lain adalah karena manusia diangkat sebagai khalifah (wakil) Allah yang bertugas memakmurkan bumi atas dasar ketakwaan. ${ }^{11}$

3. Manusia adalah makhluk berpikir yang menggunakan bahasa sebagai media. $^{12}$

4. Manusia merupakan makhluk yang memiliki tiga dimensi yang terdiri dari jasad, akal, dan jiwa. ${ }^{13}$

5. Perkembangan manusia dipengaruhi oleh beberapa factor diantaranya faktor genetik dan lingkungan. ${ }^{14}$

9 Omar Muhammad al-Toumy al-Syaibany, Falsafah Pendidikan Islam, Penerjemah: Hasan Langgulung, (Jakarta: Bulan Bintang, 1979), hal. 103-161. Bandingkan dengan Hasan langgulung, Asas-Asas Pendidikan Islam, (Jakarta: Pustaka al-Husna, cet. II. 1988), hal. 53-54.

${ }^{10}$ Lihat QS. Al-Isra': 70 dan Al-Tin: 4

${ }^{11}$ Lihat QS. Al-Baqarah: 30 dan Al-Nur: 55 tentang Kekhalifahan manusia, QS. Hud: 6 tentang memakmurkan bumi dan QS. Al-Hujurat: 13 tentang Kemuliaan berdasarkan ketakwaan.

${ }^{12}$ Al-Attas menyebut manusia sebagai binatang rasional (الحيوان النطق) maksudnya, mausia memiliki suatu fakultas batin yang berfungsi untuk merumuskan maknamakna. Perumusan itu melibatkan penilaian, perbedaan dan penjelasan sehingga membentuk rasional manusia. baca Syed M. Nquib al-Attas, Konsep Pendidikan dalam Islam, Penerjemah: Haidar Baqir, (Bandung: Mizan, cet. 3, 1988), hal. 37.

${ }^{13}$ Baca Imam Barnadib dan Sutari Imam Barnadib, Beberapa Aspek Substansial Ilmu Pendidikan, (Yogyakarta:Andi Offset, cet. I, 1996), hal. 27.

${ }^{14}$ Suatu hadist shohih yang diriwayatkan Bukhari dan Muslim menyebutkan bahwa: "Setiap anak dilahirkan dalam keadaan suci (fitrab), kedua orang tuanyalah yang dapat menjadikan ia seorang Yahudi, Nasrani, atau Majusi." Melalui hadist tersebut Islam sebenarnya ingin menunjukkan bahwa Islam tidak mengenal teori dosa asal/ waris yang memandang manusia sebagai makhluk berdosa sepanjang hidupnya.Baca Syed Sajjad Husein dan Syed Ali Ashraf,Menyongsong Keruntuhan Pendidikan IslamPenerjemah: Rahmani Astuti, (Bandung: Gema Risalah Press, cet. V, 1994), hal. 51-52. Selain itu, menurut penulis sendiri pandangan tentang manusia di atas lebih cenderung pada aliran psikologi konvergensinya William James. 
6. Manusia memilikisebuah motivasi dan kebutuhan. ${ }^{15}$

7. Secara individual manusia bersifat luwes dan selalu berubah melalui proses pendidikan.

Delapan prinsip diatas dapat membantu penelusuran filsafat untuk menentukan konsep tentang hakikat manusia. Konsepsi itu juga mencakup tentang pembahasan proses penciptaan manusia. Karenanya, pembahasan yang dimaksud tidak dapat dilepaskan dari pandangan dunia Islam.

\section{B. Proses Penciptaan Manusia}

Manusia diciptakan oleh Tuhan melalui proses secara alamiah melaluibeberapa tahapan, yaitu tahap jasad, tahap hayat, tahap ruh, dan tahap nafs, ${ }^{16}$ yang mana keempat tahap tersebut akan diuraikan sebagai berikut:

\section{Tahap Jasad (Fisik)}

Awal penciptaan manusia dalam al-Qur'an telah dijelaskansecara terperinci yakni proses awal manusia tercipta dari dari tanah (turab), ${ }^{17}$ yaitu tanah berdebu. Al-Qur'an menyebut tanah tersebut berupa istilah $\operatorname{tin}^{18}$ atau salsal. ${ }^{19}$ Yang dimaksud dengan tanah tersebut adalah saripati atau sulalah. ${ }^{20} \mathrm{Hal}$ ini bukan berarti bahwa manusia diciptakan dari bahan tanah, seperti pembuatan patung dari tanah, tetapi lebih pada makna simbolik, yaitu dari unsur dasar saripati yang

${ }^{15}$ Menurut Hasan Langgulung, membagi motivasi dalam dua kategori, yaitu motivasi primer dan sekunder, sedangkan menurut Zuhairini, manusia itu memiliki lima kebutuhan, yaitu kebutuhan biologis, psikis, sosial, agama, (spiritual) dan paudagogis(intelek), Baca Hasan Langgulung, Teori-teori Kesehatan Mental, (Jakarta: Pustaka Al-Husna, cet. 1, 1986), hal. 53-54 dan Baca Zuhairini, dkk, Filsafat Pendidikan Islam, (Jakarta: Bumi Aksara, cet. 1, 1992), hal. 53.

${ }^{16}$ Musa Asy'rie, Manusia Pembentuk Kebudayaan Menurut Al-Qur'an, (Yogyakarta: LESFI, cet. 1, 1992), hal. 62-83.

${ }^{17}$ Lihat QS. Al-Hajj: 5 dan lihat juga QS. 38 yat 71, "Ketika Tuhanmu berkata kepada Malaikat, sesunggubnya aqku menciptakan manusia dari tanab", QS. Ar-Rum (30) ayat 20: "Diantara tanda-tandanya ialab babwa Dia menciptakan kamu dari tanab".

${ }^{18}$ QS. Al-An'am: 2

${ }^{19}$ QS. Ar-Rahman: 14

${ }^{20}$ QS. Al-Mu'minun: 12 
membentuk tumbuhan atau binatang yang kemudian menjadi bahan makanan bagi manusia.

\section{Tahap Hayat}

Selain itu, dalam penjelasan lain, al-Qur'an menjelaskan bahwa, awal mula kehidupan manusia adalah air sebagaimana kehidupan tumbuhan dan binatang. ${ }^{21}$ Air yang dimaksud adalah sperma. ${ }^{22}$ Sperma kemudian membuahi sel telur di dalam rahim wanita. Sperma itulah yang merupakan bahan dasar awal mula hayat (kehidupan) seorang manusia.

\section{Tahap Ruh (jiwa)}

Ruh merupakan sesuatu yang dihembuskan Tuhan dalam diri manusia dan kemudian menjadi bagian dari diri manusia.pada saat yang sama, Tuhan juga menciptakankan pendengaran, penglihatan, dan hati bagi manusia. adanya proses peniupan ruh dalam diri manusia, yang diiringi dengan pemberian pendengaran, penglihatan, dan hati merupakan bukti bahwa yang menjadi pemimpin dalam diri manusia adalah ruh. Ruh juga yang dapat membimbing pendengaran, penglihatan, dan hati untuk memahami kebenaran.

\section{Tahap Nafs}

Dalam al-Qur'an Kata 'nafs' mengandung empat pengertian, yaitu nafsu, napas, jiwa, dan diri (keakuan). Diantara keempat pengertian tersebut, al-Qur'an lebih sering menggunakan kata 'nafs' untuk pengertian diri (keakuan).Diri atau keakuan adalah kesatuan dinamik antara jasad, hayat, dan ruh.Dinamikanya terletak pada kegiatan yang dilakukan oleh jasad, hayat, dan ruh.Kesatuannya bersifat spiritual, yang bercermin di dalam aktivitas kehidupan manusia.

Adapun dalam al-Quran di jelaskan bahwa proses penciptaan manusia mengalami beberapa tahap yang terungkap dalam surat al-Mukminun, ayat 12-14 yang berbunyi:

Dan sesunggubnya kami telah menciptakan manusia dari suatu saripati (berasal) dari tanah. Kemudian kami jadikan saripati itu air mani (yang disimpan) dalam tempat yang kokob (rabim). Kemudian air mani itu kami jadikan segumpal darah, lalu segumpal darab itu kami jadikan segumpal

\footnotetext{
${ }^{21}$ QS. Al-Anbiya': 30

${ }^{22}$ QS. Al-Sajdah: 8
} 
daging, dan segumpal daging itu kami jadikan tulang belulang, lalu tulang belulang itu kami bungkus dengan daging. Kemudian kami jadikan dia makbluk yang (berbentuk) lain. Maka Maha sucilah Allah, Pencipta yang paling baik.

Dari ayat di atas, diungkapkan bahwa proses penciptaan manusia berawal dari; pertama, saripati tanah.Kedua, sperma/air mani. Ketiga, alaqah (segumpal darah), atau embrio, keempat, segumpal daging. Kelima, segumpal daging tersebut dilengkapi dengan tulang belulang yang kemudian tulang belulang tersebut dibungkus lagi dengan daging sehingga membentuk manusia sempurna. ${ }^{23}$

\section{Tujuan Hidup Manusia}

Allah SWTmenciptakan jin dan manusia bukan tanpa tujuan yang jelas, tetapimemiliki tujuan teologis yang jelas, yaitu untuk beribadah kepada-Nya. ${ }^{24}$ Dalam hal ini ibadah dalam pengertiannya yang luas, yaitu pengabdian yang diwujudkan dalam segala rupa perkataan maupun perbuatan yang dicintai dan diridhai Allah. Pendeknya, tujuan hidup manusia di muka bumi iniyaitu menyembah terhadap Tuhan dengan cara beribadah dalam segala tingkah lakunya. ${ }^{25}$

Inti pokok dari tujuan hidup manusia samadengan tujuan pendidikan Islam, sebab pendidikan bertujuan untuk terpeliharanya kehidupan manusia. Manusia seperti apa yang hendak dibentuk dan diinginkan oleh pendidikan Islam, semuanya tergantung pada tujuan hidup yang hendak ditempuh oleh seorang muslim. Dengan demikian, tujuan hidup seorang muslim sebenarnya merupakan tujuan akhir pendidikan Islam.

\section{Kedudukan dan Tugas Manusia}

Dalam al-Qur'an sudah dijelaskan bahwa kedudukan manusia adalah sebagai khalifahAllah di muka bumu ini. Kata 'khalifab' dalam al-Qur'an

${ }^{23}$ Baca: Mansur, Mendidik Anak Sejak dalam Kandungan, (Yogyakarta: Mitra Pustaka, cet. 1, 2005), hal. 82-87. Baca juga, Quraish Shibah, Dia Ada di ManaMana; Tangan Tuban di Balik Setiap Fenomena, (Jakarta: Lentera Hati, cet. 1, 2004), hal. 111-115.

${ }^{24}$ QS. al-Dzariyat: 6

${ }^{25}$ QS. Al-An'am: 162 
telah disebutkan sebanyak $10 \mathrm{kali}^{26}$ Berdasarkan sebuah hasil penelitian bahwa dalam al-Qur'an terdapat kata khalifah, dalam bentuk tunggal sebanyak dua kali, yaitu surat al-Baqarah ayat 30 dan Shad ayat 26; dan dalam bentuk plural (jamak), yaitu Khala'if dan khulafa' yang masing-masing diulang sebanyak 4 kali dan 3 kali. ${ }^{27}$ Keseluruhan kata tersebut menurutnya berakar pada kata 'khulafa' yang pada mulanya berarti di belakang. Dari sini, kata khalifah menurutnya sering kali diartikan sebagai "pengganti” (karena yang menggantikan selalu berada atau datang dibelakang sesudah yang digantikannya ${ }^{28}$ selain diartikan sebagai pengganti. Ada beberapa pengertian yang dimaksud oleh al-Qur'an dengan kata khalifah, diantaranya: dalam hal kedudukan manusia, makna darikhalifah adalah sebagai pengganti. Jadi, seorang khalifah Allah berarti pengganti Allah. ${ }^{29}$ Menurut pendapatnya Dawam Rahardjo kata khalifah mempunyai tiga makna.Pertama, khalifab Allah yaitu Adam.Adam merupakan simbol untuk seluruh manusia, oleh karena itu, manusia termasuk darikhalifah.Kedua, khalifah Allah merupakan suatu generasi penerus.Dalam arti kedudukan khalifah diemban oleh suatu generasi.Ketiga, khalifah Allah sebagai kepala negara atau kepala pemerintahan. ${ }^{30}$ Dari ketiga makna tersebut, makna yang pertama lebih sesuai untukpredikat seorang manusia sebagai khalifah Allah.

Menurut Hasan Langgulung, ${ }^{31}$ manusia sebagai khalifah di bumi mempunyai beberapa karakteristik yaitu sebagai berikut:

1. Dari awal penciptaan, manusia secara fitrah memiliki sifat baik. Manusia tidak mewarisi dosa sekalipun Adam harus meninggalkan surga atas dosanya.

${ }^{26}$ Baca Abdullah Idi dan Toto Suharto, Revitalitas Pendidikan Islam, (Yogyakarta: Tiara Wacana, cet. 1, 2006).

${ }^{27}$ Lihat QS. al-An'am: 165, Yunus: 14, 73, Fathir: 39, Al-A'raf: 69, 74 dan al-Naml: 62.

${ }^{28}$ Baca Abuddin Nata, Filsafat Pendidikan Islam I, (Jakarta: Logos Wacana Ilmu, Cet. 1, 1997), hal. 36.

${ }^{29}$ Berkenaan dengan pertanyaan "siapa mengganti siapa" Hasan Langgulung seperti yang dikutip Abdullah Idi, mengemukakan tiga pendapat 1. Manusia sebagai makhluk menggantikan makhluk lain, yaitu jin, 2. Manusia menggantikan manusia lain, 3. Manusia adalah pengganti Allah di bumi, sehingga manusia bertindak sesuai perintah Allah, Ibid., hal. 57.

${ }^{30}$ Ibid., hal. 57-58.

${ }^{31}$ Ibid. 
2. Hubungan antara badan dengan ruh menghasilkan khalifah. Karakteristik tersebut membedakan manusia dengan makhluk lainnya.

3. Manusia sebagaikhalifahmempunyai kebebasan berkehendak (free will) yaitu suatu kebebasan yang menyebabkan manusia dapat menentukan tingkah lakunya sendiri.

4. Manusia diberi akal yang dapat membedakan perbuatan antara yang benar dan yang salah.

Sebagaimana telah dijelaskan dalam al-Qur'an tentang fungsi kekhalifahan manusia di muka bumi ini, yang berbunyi:

1. QS. al-An'am ayat 165

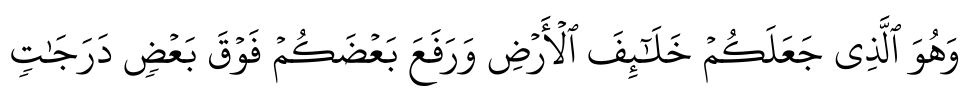

Dan dialah yang menjadikan kamu penguasa-penguasa di bumi dan dia meninggikan sebagian kamu atas sebagian (yang lain) beberapa derajat, untuk mengujimu tentang apa yang diberikan-Nya kepadamu. Sesunggubnya Tubanmu amat cepat siksaan-Nya dan sesunggubnya dia Maha Pengampun lagi Maha Penyayang.(QS. al-An'am: 165)

2. QS. al-Fatir ayat 39

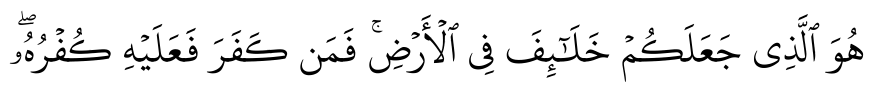

Dialah yang menjadikan kamu khalifah-khalifah di muka bumi, barangsiapa yang kafir, maka (akibat) kekafirannya menimpa dirinya sendiri.(QS. al-Fathir: 39).

3. QS. al-'Araf ayat 69

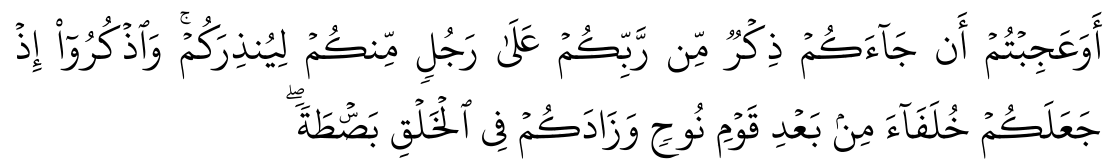

Ingatlah oleh kamu sekalian di waktu Allah menjadikan kamu sebagai pengganti-pengganti (yang berkuasa) sesudab lenyapnya kaum Nub, dan Tuban telab melebibkan kekuatan tubub dan perawakanmu (daripada kaum Nub itu). (QS. al-A'raf: 69)

Ayat-ayat diatas selain menjelaskan tentang kedudukan manusia sebagai khalifah dalam arti luas, juga memberi isyarat tentang pentingnya sikap moral yang harus ditegakkan dalam melaksanakan tugas kekhalifahan 
tersebut. ${ }^{32}$ Sebagaimana pendapatnya Quraish Shihab, bahwa hubungan antara manusia dengan alam semesta atau hubungan manusia dengan sesamanya, bukan merupakan hubungan antara penaklukdengan yang ditaklukkan, atau antara tuan dengan hamba, melainkan hubungan kebersamaan dalam ketaatannyaterhadap Allah SWT, walaupun manusia mempunyai kemampuan untuk mengelola (menguasai), namun hal tersebut bukanlahakibat kekuatan yang dimilikinya, akan tetapi akibat Tuhan menundukkannya untuk manusia. ${ }^{33}$

Hal ini sependapat dengan pendapatnya Musa Asy'ari, menurutnya; bahwa tugas seorang khalifah dalam memegang kepemimpinan dan kekuasaan, pada dasarnya mengandung tentang implikasi moral. ${ }^{34}$ Karena sifat kepemimpinan dan kekuasaan yang dimiliki oleh seorang khalifah dapat menyalahgunakan kewenangannya hanyauntuk kepentingan hawa nafsunya, atau sebaliknya kekuasaan seorang khalifah untuk menciptakan kesejahteraan dan kemaslahatanbagi manusia. Dengan demikian, kepemimpinan dan kekuasaan manusia harus sesuaidengan kerangka eksistensi manusia yang bersifat sementara, sehingga dapat dihindari kecenderungan pemutlakan kepemimpinan atau kekuasaan, yang akibatnya dapat merusak tatanan dan harmoni kehidupan. ${ }^{35}$

Kemudian dengan tujuan hidup untuk beribadah dan berkedudukan sebagai khalifah, apakah yang selanjutnya harus dikerjakan oleh manusia ?Pertanyaan itu menyangkut tugas manusia di bumi. Dalam perspektif Islam, kewajiban manusia dimuka bumi ini ialahmemakmurkan bumi dengan jalan memberikan potensi Tuhan terhadapdirinya. ${ }^{36}$ Dalam bahasa Agama, sifat-sifat Tuhan biasa disebut al-asma al-busna, yang berjumlah sembilan puluh sembilan.Sebagai contoh, oleh karena Tuhan adalah Maha Pengasih (al-Rabman), maka manusia sesungguhnya diperintahkan untuk bersifat asih terhadap dirinya dan makhluk lainnya.

Namun harus kita sadari bahwa sifat-sifat Tuhan hanya dapat dimanifestasikan manusia dalam bentuk dan cara yang terbatas. Hal itu, selain karena watak keterbatasan manusia, juga dimaksudkan agar

\footnotetext{
${ }^{32}$ Abuddin Nata, Filsafat Pendidikan Islam I, hal. 38.

${ }^{33}$ Ibid.

${ }^{34}$ Ibid.

${ }^{35}$ Ibid., hal. 38-39.

${ }^{36}$ Abdullah Idi, Revitalisasi Pendidikan Islam, hal. 58-59.
} 
manusia tidak mengaku dirinya sebagai Tuhan.sebaiknya manusia menganggap proses perwujudan sifat-sifat Tuhan sebagai suatu amanah yang harus dijalankan. Tujuannya agar manusia mempunyai tanggung jawab dalam melaksanakan tugasnya sebagai seorang hamba.

Eksistensi lain dari manusia di alam ini adalah sebagai hamba Allah yang taat beribadah kepada-Nya. Sebagaimana telah dijelaskan dalam al-Qur'an QS.al-Dzariat, yang artinya:“Tidaklah aku menciptakan jin dan manusia kecuali agar mereka menyembah (ibadab) kepada-Ku". Pengertian ibadah dalam ayat tersebut menurut Langgulung merupakan pengembangan darifitrah, yang oleh aliran kemanusiaan disebut perwujudan diri (self actualization). ${ }^{37}$

Sedangkan menurut Musa Asy'arie, bahwa essensi 'abd adalah ketaatan, ketundukan, dan kepatuhan terhadap Tuhan. ${ }^{38}$ Ketundukan dan ketaatan merupakan sebuah kodrat alamiah yang berlaku bagi kehidupan manusia.Ia terikat oleh Sunnatullah atau hukum Tuhanyang diberlakukan di alam semesta.

Dengan demikian, dapat disimpulkan bahwa kedudukan manusia di alam semesta ini disamping sebagai khalifah yang mampu untuk mengolah alam dengan menggunakan segenap potensi yang dimilikinya, juga sebagai ' $a b d$ yaitu seluruh usaha dan aktivitasnya itu harus dilaksanakan dalam rangka mengabdi kepada Allah SWT, jadi essensi seorang khalifahadalah kebebasan dan kreativitas, sedangkan seorang abd adalah ketaatan dan kepatuhan. ${ }^{39}$ Dengan pandangan yang saling keterkaitan ini, maka konsekwensi bagi seorang khalifah tidak akan berbuat sesuatu yang berhubungan dengan kemungkaran danyang bertentangan dengan aturan hukum Tuhan. Agar manusia bisa melaksanakan fungsi kekhalifahan dengan baik,maka manusia perlu diberikan pendidikan, pengajaran, pengalaman, ketrampilan, teknologi, dan sarana pendukung yang lainnya.

\section{E. Potensi Manusia}

Supaya dapat melaksanakan fungsi kekhalifahan, manusia dibekali oleh Tuhan dengan berbagai kemampuan, yang merupakan sebuah anugerah yang tidak diberikan kepada makhluk lainnya. Potensi ini

\footnotetext{
${ }^{37}$ Abuddin Nata, hal. 40.

${ }^{38}$ Ibid.

${ }^{39} \mathrm{Ibid}$., hal. 41.
} 
disebut dengansebutan fitrah. ${ }^{40}$ Sebagaimana dalam al-Qur'an yang menjelaskan tentang istilah fitrah di antaranya dalam al-Qur'an surat Ar-Rum ayat: 30 yang berbunyi:

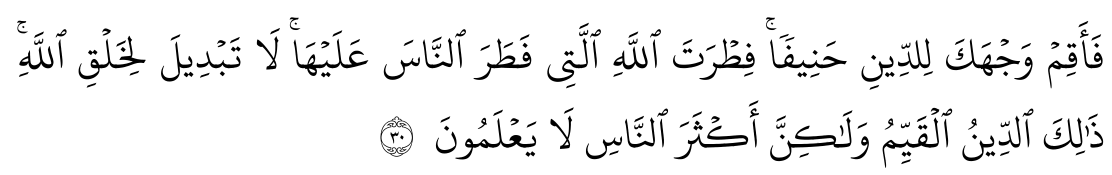

Maka hadapkanlab wajabmu dengan lurus kepada agama Allab; (tetaplah atas) fitrab Allah yang telah menciptakan manusia menurut fitrah itu. Tidak ada perubahan pada fitrah Allab (itulah) agama yang lurus; tetapi kebanyakan manusia tidak mengetabui.(QS. Ar-Rum: 30)

Dalam suatu hadis sahih riwayat al-Bukhari dan Muslim disebutkan bahwa setiap anak lahir dalam keadaan fitrab; kedua orang tuanyalah yang memungkinkan ia menjadi Yahudi, Nasrani, atau Majusi. Hadist itu mengisyaratkan bahwa sejak lahir manusia sudah dibekali potensipotensi yang disebut dengan fitrah.Fitrah adalah istilah dari bahasa Arab yang berarti tabiat suci atau tabiat baik yang khusus diciptakan oleh Tuhan untuk manusia. ${ }^{41}$ Fitrab merupakan modal dasar bagi manusia agar dapat memakmurkan bumi.Dengan demikian, fitrah merupakan potensi kodrati manusia yang harus dikembangkan demi kesempurnaan hidup. Keberhasilan manusia dapat dilihat dari kemampuannya mengembangkan fitrah.Adapun komponen dasar fitrabmanusia adalah:

1. Bakat, (kemampuan akademisdi berbagai bidang).

2. Instink, (kemampuan berbuat tanpa melalui proses belajar).

3. Nafsu dan keinginan-keinginan.

4. Karakter terbentuk secara intrinsik dalam diri manusia

5. Hereditas atau keturunan.

6. Intuisi, yaitu kemampuan kejiwaan manusia menerima ilham dari Tuhan. Intuisi ini bersifat kontruktif. ${ }^{42}$

${ }^{40}$ Abdullah Idi, Revitalisasi, hal. 59.

${ }^{41}$ Secara etimologi, asal kata fitrah dari Bahasa Arab yaitu "Fitratun" jamaknya "fitratun", artinya perangai, tbiat, kejadian asli, agama, ciptaan. Fitrah juga terambil dari akar kata "al-Fathr" yang berarti Ibelahan dari makna inilah dari maknamakna lain, antara lain "pencipta" atau kejadian baca Muis Sad Imam, "Pendidikan Partisipatif", Menimbang Konsep Fitrah Dan Progresivisme Jobn Dewey, (Yogyakarta: Safiria Insania Press, cet. 1, 2004), hal. 17.

${ }^{42}$ Ibid., hal. 25-26. 
Berkaitan dengan potensi (fitrab) yang diberikan Tuhan kepada Manusia, maka ahli filsafat memberikan beberapa predikat kepada manusia, ${ }^{43}$ antara lain sebagai berikut:

1. Manusia merupakan makhlukhomo sapiens, yang artinya makhluk bermoral atau berbudi pekerti.

2. Manusia merupakan makhlukanimale rationale, yang artinya binatang yang bisaberpikir.

3. Manusia merupakan makhlukhomo laquen, yang artinya makhluk yang pintar menciptakan bahasa.

4. Manusia merupakan makhluk homo faber, yang artinya makhluk yang pintar membuat perkakas.

5. Manusia merupakan makhluk zoon politicon, yang artinya makhluk yang pandai bekerjasama.

6. Manusia merupakan makhluk homo econornicus, yang artinya makhluk yang patuh pada prinsip-prinsip ekonomi.

7. Manusia merupakan makhluk homo relegius, yang artinya makhluk yang membutuhkan agama.

8. Manusia merupakan makhluk homo planemanel, yang artinya makhluk yang terdiri dari unsur rohaniyah-spiritual.

9. Manusia adalah homoeducandum (educable), makhluk yang dapat menerima pendidikan.

Dengan demikian, bahwaIslam memandang manusia secara optimistik, bahwa setiap manusia lahir ke dunia sudah diberi Tuhan dengan potensi (fitrab) yang baik dan suci.Hal ini bertentangan dengan pandangan pesimistik yang meniscayakan potensi yang wujud dalam diri manusia memilikiunsur kejahatan.pandangan pesimistik merupakan implikasi dari pemikiran yang menganggap manusia lahir di dunia dengan membawa dosa warisan. Di sisi lain, pandangan optimistik juga bertentangan dengan pandangan behavioristik yang melihat eksistensi manusia bersifat netral: bukan baik dan bukan jahat; atau yang dikenal dengan istilah tabula rasa, putih seperti kertas. Dengan demikian, dapat dikatakan bahwa pandangan Islam merupakan pandangan yang mensintesakan pandangan pesimistik dan pandangan behavioristik.

${ }^{43}$ Zuhairini, dkk, Filsafat Pendidikan Islam, hal. 82. 


\section{PENUTUP}

Manusia dianggap sebagai makhluk paling mulia di alam semesta ini. Allah telah memberikan keistimewaan-keistimewaan yang menyebabkan manusia berhak mengungguli makhluk lain. Kemuliaan manusia atas makhluk lain ialahsebab manusia diangkat sebagai khalifah (wakil) Allah yang bertugas melestarikan alam semestaberdasarkan ketakwaan. Manusia dilahirkan ke dunia oleh Tuhan melalui proses yang natural yang berlangsung dalam beberapa tingkatanyaitu pertama, jasad, kedua hayat, ketiga, ruh, dan keempatnafs. Awal proses diciptakannya manusiayaitu sebagai berikut; pertama, awal dicipatakan dari saripati tanah, kedua, dari saripati tanah berubah menjadi sperma/air mani, ketiga, dari sperma berubah menjadi alaqah (segumpal darah), atau embrio, keempat, dari segumpal darah (alaqab) berubah menjadi segumpal daging, kelima, dari segumpal daging tersebut disempurnakan dengan tulang belulang yang kemudian tulang belulang tersebut dibungkus lagi dengan daging sehingga membentuk manusia sempurna.Tugas seorang khalifah, sebagai pengganti yang memegang kepemimpinan dan kekuasaan, pada dasarnya mengandung implikasi moral.Karena kepemimpinan dan kekuasaan yang dimiliki seorang khalifah dapat disalahgunakan untuk kepentingan mengejar kepentingan hawa nafsunya, atau sebaliknya juga dapat dipakai untuk kepentingan menciptakan kesejahteraan hidup bersama.Disamping itu, menurut pandangan Islam, tugasdari manusiaialah memakmurkan alam semesta dengan caramengolah potensi Tuhan dalam dirinya. Dengan kata lain, manusia diperintahkan untuk mengembangkan sifat-sifat dari Tuhan menurut perintah dan petunjuk-Nya. Dalam istilah Agama, sifat-sifat Tuhan disebutdengan al-asma al-busna. Dalam melaksanakan fungsi kekhalifahan manusia perlu diberikan pendidikan, pengajaran, pengalaman, teknologi, dan sarana pendukung lainnya. Oleh karena itu, manusia dibekali oleh Tuhan beberapa potensi, dan juga anugerah yang tidak diberikan oleh Tuhan kepada makhluk lain. Potensi-potensi itu disebut fitrah. 


\section{DAFTAR PUSTAKA}

Al-Attas, Syed M. Naquib, Konsep Pendidikan dalam Islam, Penerjemah: Haidar Baqir, Bandung: Mizan, cet. 3, 1988.

Al-Toumy al-Syaibany, Omar Muhammad, Falsafah Pendidikan Islam, Jakarta: Bulan Bintang, 1979.

Asy'rie, Musa, Manusia Pembentuk Kebudayaan Menurut Al-Qur'an, Yogyakarta: LESFI, cet. 1, 1992.

Barnadib, Imam dan Sutari Imam Barnadib, Beberapa Aspek Substansial Ilmu Pendidikan, Yogyakarta:Andi Offset, cet. I, 1996.

Husein, Syed Sajjad dan Syed Ali Ashraf, Menyongsong Keruntuhan Pendidikan IslamPenerjemah: Rahmani Astuti, Bandung: Gema Risalah Press, cet. V, 1994.

Idi,Abdullah dan Toto Suharto, Revitalitas Pendidikan Islam, Yogyakarta: Tiara Wacana, 2006.

Imam, Muis Sad "Pendidikan Partisipatif", Menimbang Konsep Fitrah Dan Progresivisme John Dewey, Yogyakarta: Safiria Insania Press, 2004.

Langgulung, Hasan, Asas-Asas Pendidikan Islam,Jakarta: Pustaka alHusna, cet. II. 1988.

1, 1986.

Mansur, Mendidik Anak Sejak dalam Kandungan, Yogyakarta: Mitra Pustaka, cet. 1, 2005.

Nata, Abuddin, Filsafat Pendidikan Islam I, Jakarta: Logos Wacana Ilmu, Cet. 1, 1997.

S. Suriasumantri, Jujun, Filsafat Ilmu: Sebuah Pengantar Populer, Jakarta: Pustaka Sinar Harapan.

Shibah, Quraish, Dia di Mana-Mana; Tangan Tuhan di Balik Setiap Fenomena, Jakarta: Lentera Hati, 2004.

Zuhairini, dkk, Filsafat Pendidikan Islam, Jakarta: Bumi Aksara, cet. 1, 1992. 